\title{
A Self-Assembled AMF-Responsive Nanoplatform Based on Pillar[5]arene and Superparamagnetic Nanoparticles for Controlled Release of Doxorubicin
}

\author{
Tamires S. Fernandes, ${ }^{a}$ Evelyn C. S. Santos, ${ }^{a, b}$ Vinicius G. C. Madriaga, ${ }^{a}$ \\ Isabela A. A. Bessa, ${ }^{a}$ Vanessa Nascimento, ${ }^{a}$ Flávio Garcia $^{b}$ and Célia M. Ronconi ${ }^{\circledR} * a$ \\ ${ }^{a}$ Departamento de Química Inorgânica, Universidade Federal Fluminense, Campus do Valonguinho, \\ Outeiro São João Batista s/n, Centro, 24020-150 Niterói-RJ, Brazil \\ ${ }^{b}$ Centro Brasileiro de Pesquisas Físicas (CBPF), Rua Dr Xavier Sigaud 150, Urca, \\ 22290-180 Rio de Janeiro-RJ, Brazil
}

\begin{abstract}
An alternating magnetic field (AMF)-stimuli responsive nanodevice based on magnetic nanoparticles (MNP) functionalized with water-soluble carboxylate-substituted pillar[5]arene (CP[5]A), namely MNP-CP[5]A, as a multiplatform for cancer treatment has been designed. MNP-CP[5]A was loaded with doxorubicin (DOX), showing a loading capacity of $9.5 \mathrm{mg} \mathrm{g}^{-1}$. The nanodevice demonstrated good colloidal stability, superparamagnetic behavior, and was capable to generate detectable heat in solution induced by AMF application. DOX release, monitored by ultraviolet-visible (UV-Vis) spectroscopy, was investigated by varying the temperature (37 and $45{ }^{\circ} \mathrm{C}$ ) without AMF and in the presence of AMF (frequency (f) $=307 \mathrm{kHz}$, field amplitude $\left.(\mathrm{H})=200 \mathrm{Oe}, 45^{\circ} \mathrm{C}\right)$ at $\mathrm{pH}=7.4$. Thermo-induced DOX release without AMF was $1.9 \%\left(1.8 \mu \mathrm{g} \mathrm{mL}^{-1}\right)$ and $2.3 \%\left(3.3 \mu \mathrm{g} \mathrm{mL}^{-1}\right)$ at 37 , and $45{ }^{\circ} \mathrm{C}$ within $50 \mathrm{~min}$, respectively. In an AMF DOX release increased to $5.7 \%\left(8.2 \mu \mathrm{g} \mathrm{mL}^{-1}\right)$ within $50 \mathrm{~min}$. Therefore, MNP-CP[5]A-DOX works as a chemo-hyperthermia nanodevice.
\end{abstract}

Keywords: carboxylate-substituted pillar[5]arene, superparamagnetic nanoparticles, magnetic hyperthermia, doxorubicin delivery, cancer

\section{Introduction}

The most used treatments for cancer cells are chemotherapy and radiotherapy; however, they lead to undesirable side effects. Hyperthermia is an alternative treatment, in which the cancer cells are killed or damaged by exposing body tissues to high temperatures (up to $\left.45^{\circ} \mathrm{C}\right) .{ }^{1}$ Cancer cells are more sensitive to temperature increase than the healthy ones because their disorganized and compact vascular structures are unable to dissipate heat efficiently. ${ }^{2}$ Such treatment can be applied to different body extensions, ranging from small cell volumes to organs, and even the whole body. ${ }^{3,4}$ The necessary heat can be generated by different approaches, e.g. ultrasound, microwaves, nearinfrared radiation, or alternated magnetic field. ${ }^{1,3-6}$

Magnetic nanoparticles for hyperthermia-based therapy are gaining attention in the biomedical field. ${ }^{7-9}$ In the treatment using magnetic hyperthermia $(\mathrm{MH})$, the heat is locally generated when hyperthermia-inducing agents, such as magnetic nanoparticles (MNP) are submitted to an

*e-mail: cmronconi@id.uff.br alternating magnetic field (AMF) of appropriate frequency and amplitude. ${ }^{10}$ The advantages of $\mathrm{MH}$ in cancer treatment are that AMF penetration is deeper than any other stimulus and avoids body tissues damage caused by the ionizing radiation. Moreover, this modality is potentially selective to tumor cells and can be used as a combinatory treatment improving the effects of radiotherapy or chemotherapy., ${ }^{3,11,12}$

Among hyperthermia-inducing nanomaterials, superparamagnetic iron oxide nanoparticles (SPIONs) ${ }^{13,14}$ are considered the best candidates because they are biocompatible and show a zero residual magnetization in the absence of an external magnetic field. The superparamagnetic behavior along with appropriate coating of the nanoparticles can avoid thrombosis caused by their agglomeration. ${ }^{15}$ Moreover, iron oxide nanoparticles have the approval of U.S. Food and Drug Administration (FDA) for biomedical applications. ${ }^{16,17}$

Coating bare SPIONs with biocompatible materials to avoid aggregation and consequently guarantee the stability of colloidal dispersions is an important step in the design of efficient nanocarriers. ${ }^{18}$ To address this issue, several inorganic and organic materials can be 
used to cover nanoparticles surface, such as silica, ${ }^{19-21}$ citric acid, ${ }^{14,22}$ dextran ${ }^{23}$ and macrocycles. ${ }^{24-29}$ Recently, pillar[n]arenes $(\mathrm{P}[\mathrm{n}] \mathrm{A})$, a new class of macrocycles derived from paracyclophanes, have emerged as biocompatible components for drug delivery systems and for many other biological applications..$^{30,31}$ The electron-rich cavity and possible chemical modification on the upper and lower rims of $\mathrm{P}[\mathrm{n}] \mathrm{A}$ can provide very useful water-soluble macrocycles with hydrophobic voids. ${ }^{32}$ Thus, anionic and cationic watersoluble pillar[n]arenes have been widely explored as hosts for chemotherapeutic drugs ${ }^{33,34}$ as well as micelles, ${ }^{35,36}$ vesicles, ${ }^{36-41}$ and gatekeepers in nanovalve systems. ${ }^{42-47}$

To the best of our knowledge, the combination of watersoluble carboxylate-substituted pillar[5]arene (CP[5]A) grafted onto SPIONs as an AMF stimuli-responsive nanodevice for drug delivery has not been described in the literature. Magnetite coated with CP[5]A has been reported for environmental applications, such as dye separation, ${ }^{48}$ pesticide detection in beverages ${ }^{49}$ and used as gatekeepers in nanovalves for hormone delivery to plants. ${ }^{47}$ For biomedical applications, SPIONs coated with metalorganic frameworks (MOFs) have been used as reservoir for fluorouracil (an anticancer drug), gated with carboxylatesubstituted pillar[6]arene (CP[6]A) and investigated as a theranostic nanoplatform..$^{50}$

Therefore, our goal in this work is to develop a novel chemo-hyperthermia nanodevice based on watersoluble carboxylate-substituted pillar[5]arene CP[5]A and SPIONs, namely MNP-CP[5]A (Scheme 1). The interaction between the anticancer drug (doxorubicin, DOX) and CP[5]A has not been reported in the literature and, in this work, we investigated it by ${ }^{1} \mathrm{H}$ nuclear magnetic resonance (NMR) spectroscopy and the stoichiometry of the interaction was evaluated by the method of continuous variation (Job plot). The nanodevice was successfully prepared in three steps (Scheme 1): (i) synthesis of carboxylate-substituted pillar[5]arene (CP[5]A); (ii) synthesis of SPIONs using coprecipitation method; and (iii) functionalization of SPIONs with CP[5]A. The final material (MNP-CP[5]A) and their precursors were characterized by several techniques and loaded with doxorubicin (DOX). DOX release studies were carried out in phosphate buffered saline (PBS, pH 7.4) without AMF application at 37 (body temperature) and $45^{\circ} \mathrm{C}$ (hyperthermia temperature), and also in the presence of AMF at $45^{\circ} \mathrm{C}$.

\section{Experimental}

Materials and methods

The reagents and solvents were used as received: 1,4-dimethoxybenzene (99\%), paraformaldehyde (practical grade, p.a.), boron trifluoride diethyl etherate (p.a.), boron tribromide ( $\geq 99 \%)$, ethyl bromoacetate $(98 \%)$, potassium iodide ( $\geq 99 \%$ ), iron(II) chloride tetrahydrate ( $\geq 99 \%$ ), iron(III) chloride anhydrous $(\geq 97 \%)$, doxorubicin hydrochloride (98\%), potassium nitrate ( $\geq 99 \%)$, sodium phosphate dibasic (98\%), and potassium phosphate monobasic (98\%) were purchased from Sigma-Aldrich (St. Louis, USA). All solvents, potassium carbonate (p.a.), ammonium hydroxide (30-34\%), hydrochloric acid (37\%),

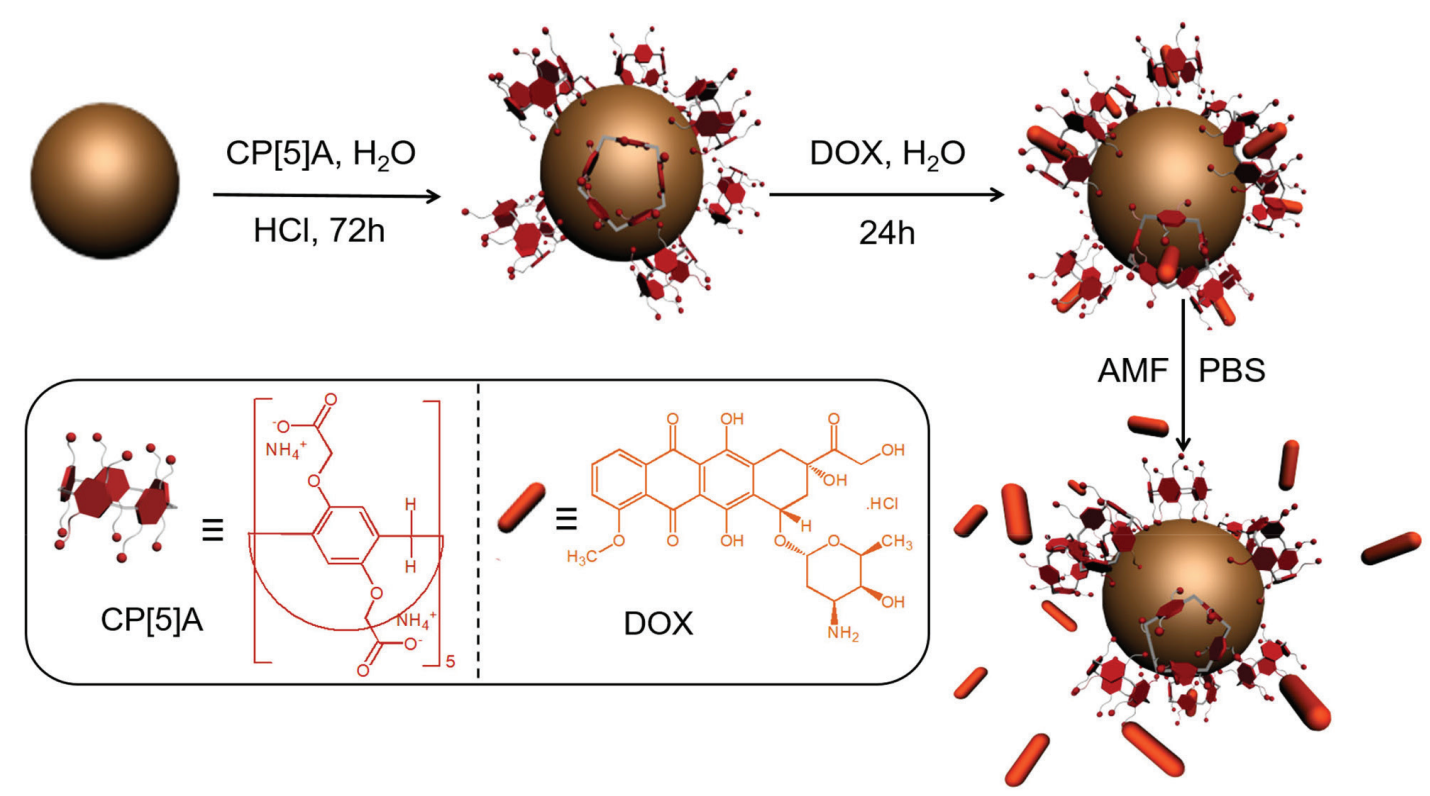

Scheme 1. Representation of the preparation of MNP-CP[5]A-DOX nanodevice and doxorubicin (DOX) release in the presence of an alternating magnetic field (AMF). 
nitric acid ( $\geq 65 \%)$ were purchased from Vetec (Rio de Janeiro, Brazil).

${ }^{1} \mathrm{H}$ and ${ }^{13} \mathrm{C}$ nuclear magnetic resonance (NMR) spectra of the ammonium carboxylate-substituted pillar[5]arene salt were measured at room temperature (RT) on a Varian VNMRS at 500 and $125 \mathrm{MHz}$, respectively, using residual solvent as internal standards. The sample was prepared using $\mathrm{D}_{2} \mathrm{O}$ purchased from Cambridge Isotope Laboratories (Tewksbury, USA). Attenuated total reflection Fourier-transform infrared (ATR-FTIR) spectra were obtained in the range $4000-500 \mathrm{~cm}^{-1}$ using a Thermo Nicolet iS50 instrument. Thermogravimetric analyses (TGA) were acquired using a Shimadzu DTG-60/60H instrument. The samples were heated from 30 to $600{ }^{\circ} \mathrm{C}$ at a heating rate of $5{ }^{\circ} \mathrm{C} \mathrm{min}-1$ and a nitrogen flow of $50 \mathrm{~cm}^{3} \mathrm{~min}^{-1}$. Powder $\mathrm{X}$-ray diffraction (PXRD) analyses were carried out on a Bruker D8 Advance X-ray diffractometer with $\mathrm{CuK} \alpha$ $\left(\lambda=1.5418 \AA\right.$ ) within a $2 \theta$ range of $10-100^{\circ}$ and indexed with the Joint Committee on Powder Diffraction Data (JCPDS) cards from International Center for Diffraction Data and the crystallite size (D) calculated from Scherrer's equation 1:

$\mathrm{D}=\frac{\mathrm{K} \lambda}{\beta \cos \theta}$

where $\mathrm{K}$ is the proportionality constant; $\lambda$ is the $\mathrm{X}$-ray wavelength; $\beta$ is the peak width in full width at half maximum (FWHM); and $\theta$ is the Bragg's diffraction angle.

Transmission electron microscopy (TEM) was performed on a JEOL JEM-1011 instrument operated at an accelerating voltage of $80 \mathrm{kV}$. Magnetic properties were measured in a magnetometer Quantum Design MPMS3 using a SQUID (superconducting quantum interference device) sensor. Zeta potential ( $\zeta$-potential) and hydrodynamic diameter measurements were carried out with a Zetasizer Nano ZS90 instrument by Malvern Instruments. The $\zeta$-potential of MNP-CP[5]A $\left(0.075 \mathrm{mg} \mathrm{mL}^{-1}\right)$ was measured in $\mathrm{KNO}_{3}$ solution $\left(0.01 \mathrm{~mol} \mathrm{~L}^{-1}\right)$ at $\mathrm{pH}$ values ranging from 2 to 10 . The hydrodynamic diameter was measured in PBS (phosphate buffered saline) buffer at $\mathrm{pH}=7.4$. Ultraviolet-visible (UV-Vis) absorption spectra were acquired using a Cary $60 \mathrm{UV}$-Vis spectrophotometer Agilent.

\section{Synthesis of the ammonium carboxylate-substituted pillar[5] arene salt $(\mathrm{CP}[5] \mathrm{A})$}

The synthesis of water-soluble ammonium carboxylatesubstituted pillar[5]arene salt (CP[5]A) was carried out in five steps following a procedure described in the literature ${ }^{51-53}$ with modifications (Scheme S1, Supplementary Information
(SI) section). Briefly, under stirring in an inert atmosphere, paraformaldehyde $(44.9 \mathrm{mmol})$ and trifluoride diethyl etherate $(14.68 \mathrm{mmol})$ was added to a 1,4-dimethoxybenzene (14.48 mmol) solution in 1,2-dichloroethane ( $30 \mathrm{~mL})$. Then, the solution was poured in $\mathrm{MeOH}$ and the solid formed collected by filtration, yielding $92 \%$ of compound $\mathbf{1}$ as a yellowish solid after purification. A solution of compound $\mathbf{1}$ $(1.83 \mathrm{mmol})$ and boron tribromide $(89.28 \mathrm{mmol})$ in dry $\mathrm{CH}_{2} \mathrm{Cl}_{2}$ was stirred under an inert atmosphere and at room temperature for 4 days, then $\mathrm{H}_{2} \mathrm{O}$ was poured to the reaction mixture and left under stirring for additional 3 days. The solid formed was collected by filtration, washed with $\mathrm{H}_{2} \mathrm{O}$ and dried under vacuum to yield compound $2(90 \%)$ as a white solid after purification. To a mixture of compound $\mathbf{2}$ $(1.65 \mathrm{mmol})$ and $\mathrm{K}_{2} \mathrm{CO}_{3}(20.97 \mathrm{mmol})$ in $\mathrm{CH}_{3} \mathrm{CN}$, KI $(30 \mathrm{mg})$ and ethyl bromoacetate $(17.67 \mathrm{mmol})$ were added and the reaction mixture was left under reflux for $15 \mathrm{~h}$. The mixture was filtered, concentrated under vacuum, and the residue purified by crystallization, yielding $41 \%$ of compound $\mathbf{3}$. To a solution of compound $\mathbf{3}(6.93 \mathrm{mmol})$ in $\mathrm{EtOH}$, an aqueous solution $\mathrm{NaOH}(40 \%)$ was added, and the reaction was stirred under reflux for $10 \mathrm{~h}$. The mixture was concentrated under vacuum and dissolved in $\mathrm{H}_{2} \mathrm{O}$. Then $\mathrm{HCl}$ was added and the resulting solid collected, washed with $\mathrm{H}_{2} \mathrm{O}$, and dried under vacuum to yield compound $\mathbf{4}$ (P[5]A, 55\%). A solution of $4(0.168 \mathrm{mmol})$ in $\mathrm{H}_{2} \mathrm{O}$ was stirred with $\mathrm{NH}_{4} \mathrm{OH}$ for $5 \mathrm{~h}$. The mixture was concentrated under vacuum and the final product, $\mathrm{CP}[5] \mathrm{A}$, obtained in $100 \%$ yield as a yellow solid. ATR-FTIR $v / \mathrm{cm}^{-1} 1571$, 1497, 1429, 1399, 1330, 1198, 1063; ${ }^{1} \mathrm{H}$ NMR (500 MHz, $\left.\mathrm{D}_{2} \mathrm{O}\right) \delta 6.73$ (s, 10H, Ar-H), $4.28\left(\mathrm{~s}, 20 \mathrm{H}, \mathrm{CH}_{2}\right), 3.84(\mathrm{~s}$, $\left.10 \mathrm{H}, \mathrm{CH}_{2}\right) ;{ }^{13} \mathrm{C}$ NMR $\left(125 \mathrm{MHz}, \mathrm{D}_{2} \mathrm{O}\right) \delta 177.07,129.45$, $128.8,115.06,67.81,29.40$.

\section{Preparation of magnetic nanoparticles (MNP)}

Magnetic nanoparticles (MNP) were synthesized by Massart method with minor modifications, followed by a nitric acid treatment to achieve maghemite phase. ${ }^{14,54}$ Briefly, under $\mathrm{N}_{2}$ atmosphere an aqueous solution containing both $\mathrm{FeCl}_{2} \cdot 4 \mathrm{H}_{2} \mathrm{O}\left(50 \mathrm{~mL}, 0.33 \mathrm{~mol} \mathrm{~L}^{-1}\right)$ and $\mathrm{FeCl}_{3}(50 \mathrm{~mL}$, $0.66 \mathrm{~mol} \mathrm{~L}^{-1}$ ) were added to an aqueous $\mathrm{NH}_{4} \mathrm{OH}$ solution (450 mL, 30\%) under vigorous mechanical stirring. The reaction mixture remained under $\mathrm{N}_{2}$ atmosphere for $1 \mathrm{~h}$ at $90{ }^{\circ} \mathrm{C}$. Then, the black solid was separated from the solution using a magnet and washed with distilled water until $\mathrm{pH}=7.0$. The nanoparticles were oxidized to obtain the maghemite phase by treating the resulting solid with $\mathrm{HNO}_{3}\left(300 \mathrm{~mL}, 2 \mathrm{~mol} \mathrm{~L}^{-1}\right)$ under mechanical stirring during $15 \mathrm{~min}$. The supernatant was removed and a solution of $\mathrm{Fe}\left(\mathrm{NO}_{3}\right)_{3}\left(75 \mathrm{~mL}, 1 \mathrm{~mol} \mathrm{~L}^{-1}\right)$ was added to the nanoparticles. 
After 30 min under reflux, the supernatant was removed and another aliquot of $\mathrm{HNO}_{3}\left(300 \mathrm{~mL}, 2 \mathrm{~mol} \mathrm{~L}^{-1}\right)$ was added and the mixture remained under stirring for further $15 \mathrm{~min}$. The nanoparticles were isolated using magnetic decantation, washed with acetone $(4 \times)$, and dried under vacuum $(8 \mathrm{~h})$ to yield a brownish solid (3.67 g) named MNP.

\section{Preparation of the MNP-CP[5]A}

The MNP surface was functionalized with CP[5]A based on a procedure described in the literature with modifications. ${ }^{14}$ The magnetic nanoparticles $(0.8 \mathrm{~g})$ were dispersed in deionized water $(96 \mathrm{~mL})$ using an ultrasound bath for $15 \mathrm{~min}$, then $\mathrm{HCl}\left(0.4 \mathrm{~mL}, 12 \mathrm{~mol} \mathrm{~L}^{-1}\right)$ was added up to $\mathrm{pH}=2.0$. The dispersion was mechanically stirred and then ammonium carboxylate-substituted CP[5]A salt $(0.48 \mathrm{mmol})$ dissolved in deionized water was quickly added in one portion to the suspension. After $72 \mathrm{~h}$ of stirring at RT, the brownish solid was collected with a magnet, washed with distilled water up to $\mathrm{pH}=7.0$, and purified using a dialysis bag of cellulose membrane ( $14 \mathrm{kDa}$, SigmaAldrich). The final product was dried under vacuum for $8 \mathrm{~h}$ and named MNP-CP[5]A (1.1 g).

\section{Magnetic hyperthermia capability of MNP-CP[5]A}

The capacity of MNP-CP[5]A to generate heat (magnetic hyperthermia) in an AMF was investigated using a magnetic hyperthermia induction system (Nanoscale Biomagnetics DM2-s53) equipped with vacuum shield as thermal insulation and an optic fiber temperature probe. The nanoparticles were placed in a $2 \mathrm{~mL}$ vial sample holder containing PBS buffer $(\mathrm{pH}=7.4)$, and their final concentrations were $1,5,10,15$, and $20 \mathrm{mg} \mathrm{mL}^{-1}$. After the introduction of each vial on the middle of the instrument coil, the samples were subjected to AMF at fixed frequency (f) of $307 \mathrm{kHz}$ and field amplitude (H) of $200 \mathrm{Oe}$ during $50 \mathrm{~min}$. The heating temperature was detected and plotted against time.

\section{Interaction between DOX and CP[5]A}

${ }^{1} \mathrm{H}$ NMR spectrum of an equimolar $(2.45 \mu \mathrm{mol})$ mixture of CP[5]A and DOX were recorded in $\mathrm{D}_{2} \mathrm{O}(700 \mu \mathrm{L})$ at RT. The stoichiometry of the interaction between CP[5]A and DOX was evaluated by the method of continuous variation (Job plot), through UV-Vis spectroscopy data. The UV-Vis experiments were carried out by mixing different volumes of two aqueous solutions of CP[5]A and DOX in the same concentrations $\left([\mathrm{CP}[5] \mathrm{A}]=[\mathrm{DOX}]=3 \times 10^{-5} \mathrm{~mol} \mathrm{~L}^{-1}\right)$. The mixture of both solutions was carried out keeping the same final volume in the quartz cuvette $(3 \mathrm{~mL})$. The molar proportion between the two compounds changed from 0 to 1 .

\section{DOX loading of MNP-CP[5]A}

MNP-CP[5]A (0.100 g) dispersed in $80 \mathrm{~mL}$ of a DOX water solution $\left(0.0175 \mathrm{mg} \mathrm{mL}^{-1}\right)$ light-protected was gently shaken $(100 \mathrm{rpm})$ for $24 \mathrm{~h}$ at RT. After this period, MNP-CP[5]A was collected using a magnet and the excess of DOX was removed from the solid through several washing steps. The solid was dried under vacuum at RT for $8 \mathrm{~h}$, yielding MNP-CP[5]A-DOX. The supernatants were collected to calculate drug-loading efficiency. The amount of DOX loaded into MNP-CP[5]A-DOX was determined using the DOX standard curve from the difference between the initial DOX concentration $\left(0.0175 \mathrm{mg} \mathrm{mL}^{-1}\right)$ in solution and the remaining DOX concentration in the supernatant after a period of $24 \mathrm{~h}$ in contact with the MNP-CP[5]A plus washing waters. DOX standard curve was constructed according to the measurement of series of concentrations of DOX solutions in water $\left(1,10,20,30,40,50 \mathrm{mg} \mathrm{L}^{-1}\right)$ at $\lambda=483 \mathrm{~nm}$ (Figure S7, SI section). The calculated amount of DOX loaded in the nanocarrier was $9.5 \mathrm{mg} \mathrm{g}^{-1}$. DOX-loading efficiency was calculated using equation 2 where $\mathrm{m}_{\text {DOX-Loaded }}$ is the mass of DOX in the nanocarrier after loading and $\mathrm{m}_{\text {DOX-Initial }}$ is the initial mass of DOX used. The DOX-loading efficiency for MNP-CP[5]A-DOX was $68 \%$.

DOX-loading efficiency $(\%)=\mathrm{m}_{\text {DoX-Loaded }} / \mathrm{m}_{\text {DoX-Initial }} \times 100$

DOX release behavior as function of temperature without AMF application

The experiments were carried out at $37{ }^{\circ} \mathrm{C}$ (body temperature) and $45{ }^{\circ} \mathrm{C}$ (hyperthermia temperature) at physiological pH (7.4). MNP-CP[5]A (15 mg) was placed in a quartz cuvette containing $1 \mathrm{~mL}$ of PBS buffer and the dispersed nanoparticles were decanted using a magnet. Then, the cuvette was introduced into the preheated thermoelectric controlled cuvette holder of the UV-Vis spectrophotometer, at 37 or $45^{\circ} \mathrm{C}$. A spectrum was acquired every $10 \mathrm{~min}$ during $50 \mathrm{~min}$.

\section{DOX release behavior of MNP-CP[5]A-DOX in an AMF}

A glass vial containing a dispersion of $15 \mathrm{mg}$ of MNP-CP[5]A-DOX in PBS buffer (1 mL, pH 7.4) was introduced in the magnetic induction heating instrument (Nanoscale Biomagnetics DM2-s53). After stabilization of the internal temperature $\left(23-25{ }^{\circ} \mathrm{C}\right)$, the samples were 
submitted to an AMF with frequency (f) of $307 \mathrm{kHz}$ and field amplitude $(\mathrm{H})$ of 200 Oe for $0,10,20,30,40$, and $50 \mathrm{~min}$ until reaching the temperature of $45 \pm 1{ }^{\circ} \mathrm{C}$ (hyperthermia temperature). Then, the temperature remained constant by controlling the field amplitude $(\mathrm{H})$. The nanoparticles were magnetically decanted, and the supernatant was collected and analyzed by UV-Vis spectroscopy.

\section{Results and Discussion}

\section{Synthesis and characterization of MNP-CP[5]A}

CP[5]A was synthesized in five steps (Scheme S1, SI section). ${ }^{51-53}$ 1,4-Dimethoxybenzene (1), a hydroquinone derivative, was cyclized by reacting with paraformaldehyde in the presence of a Lewis acid $\mathrm{BF}_{3} \cdot \mathrm{OEt}_{2}$, and the solvent 1,2-dichloroethane as template. Then, dimethoxypillar[5]arene (2) was O-demethylated with boron tribromide, and the pillar[5]arene (3) reacted with ethyl bromoacetate through $\mathrm{S}_{\mathrm{N}} 2$ reaction to obtain the ester pillar[5]arene (4). The carboxylic acid pillar[5]arene (5) was obtained after refluxing it with $\mathrm{NaOH}$ aqueous solution followed by an acidification reaction. Finally, the reaction of (5) with $\mathrm{NH}_{4} \mathrm{OH}$ provided the water-soluble ammonium carboxylate-substituted pillar[5]arene salt, $\mathrm{CP}[5] \mathrm{A}(\mathbf{6}) .{ }^{1} \mathrm{H}$ and ${ }^{13} \mathrm{C}$ NMR spectra of CP[5]A in $\mathrm{D}_{2} \mathrm{O}$ confirmed the formation of the macrocycle (Figures $\mathrm{S} 1$ and S2, SI section).

Superparamagnetic magnetite nanoparticles were prepared by coprecipitation employing Massart method ${ }^{54}$ followed by nitric acid treatment to obtain maghemite phase, which is more stable than magnetite at ambient conditions. ${ }^{55}$ In addition, the acid treatment was carried out because the functionalization process with $\mathrm{CP}[5] \mathrm{A}$ was better succeeded under acid conditions $(\mathrm{pH}=2)$, which certainly would oxidize and change the nanoparticle surface during the functionalization process. Therefore, the nanoparticles were subjected to a previous controlled oxidation.

The ATR-FTIR spectra of MNP, CP[5]A and MNP-CP[5]A are depicted in Figure 1. In the MNP spectrum, the broad band at $3200-3550 \mathrm{~cm}^{-1}$ region and the intense band at $1615 \mathrm{~cm}^{-1}$ are associated to $\mathrm{OH}$ groups and water present on the surface of MNP, whereas the bands in the range of $1300-1255 \mathrm{~cm}^{-1}$ are of nitrate anions from the acid treatment. The intense bands at 623 and $529 \mathrm{~cm}^{-1}$ are related to the stretching vibrations of $\mathrm{Fe}-\mathrm{O}$ bonds of maghemite bulk. ${ }^{14}$ These bands were also observed in the MNP-CP[5]A spectrum. The grafting of CP[5]A onto MNP was confirmed by the bands at 1715,1608 , and $1400 \mathrm{~cm}^{-1}$, which are assigned to $v(\mathrm{C}=\mathrm{OOH}), v\left(\mathrm{C}=\mathrm{OO}^{-}\right)_{\text {asym }}$ and
$v\left(\mathrm{C}-\mathrm{OO}^{-}\right)_{\mathrm{sym}}$ stretching vibrations, respectively. The bands associated to nitrate anions disappeared in the spectrum of MNP-CP[5]A, indicating these groups were replaced by the carboxylate groups of CP[5]A. The band at $1715 \mathrm{~cm}^{-1}$ indicates some CP[5]A remains in the acid form due to acid $\mathrm{pH}$ used in the synthesis. However, a displacement $\left(\Delta \mathrm{v}_{\mathrm{C}=\mathrm{OOH}}=5 \mathrm{~cm}^{-1}\right)$ of this band in comparison to carbonyl band at $1720 \mathrm{~cm}^{-1}$ of acid pillar[5] arene (P[5]A, Figure S3, SI section) indicates the acid groups of $\mathrm{P}[5] \mathrm{A}$ might be coordinated to $\mathrm{Fe}^{\mathrm{III}}$ ion. ${ }^{56}$

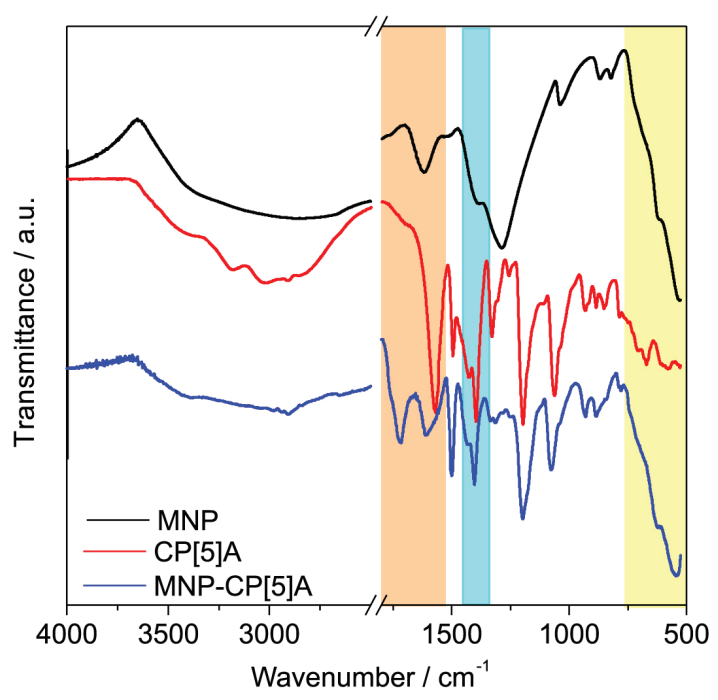

Figure 1. ATR-FTIR spectra of MNP-CP[5]A and its precursors.

Thermogravimetric analyses (TGA) exhibit two main decomposition steps for MNP-CP[5]A and its precursors (Figure S4, SI section). The initial weight loss at approximately $100{ }^{\circ} \mathrm{C}$ may be related to elimination of adsorbed solvent molecules on the surface of all materials. The second weight loss for MNP, CP[5]A and MNP-CP[5]A was $7.3,34.2$, and $67.6 \%$ at temperatures ranging from 100 to $600{ }^{\circ} \mathrm{C}$. This second weight loss for MNP-CP[5]A starts at approximately $150{ }^{\circ} \mathrm{C}$ due to decomposition of $\mathrm{CP}[5] \mathrm{A}$ molecules. From TGA results, the calculated amount of $\mathrm{CP}$ [5]A anchored onto the surface of MNP was $0.27 \mathrm{mg}$ of CP[5]A per mg of MNP-CP[5]A. Therefore, CP[5]A was successfully grafted onto MNP surface.

Powder X-ray diffraction (PXRD) patterns of MNP and MNP-CP[5]A are shown in Figure 2. We would expect the formation of maghemite phase due to the oxidation process of the MNP with nitric acid. However, because PXRD patterns of maghemite $\left(\gamma-\mathrm{Fe}_{2} \mathrm{O}_{3}\right.$, JCPDS 39-1346) and magnetite $\left(\mathrm{Fe}_{3} \mathrm{O}_{4}\right.$, JCPDS 19-629) phases are very similar we cannot discharge the formation of both phases in the materials. PXRD also shows the MNP does not undergo relevant changes in its crystallinity after $\mathrm{CP}$ [5]A coating. Using Scherrer's equation 1, the calculated crystallite 
sizes of the nanoparticles were $11 \mathrm{~nm}$ for both MNP and MNP-CP[5]A.

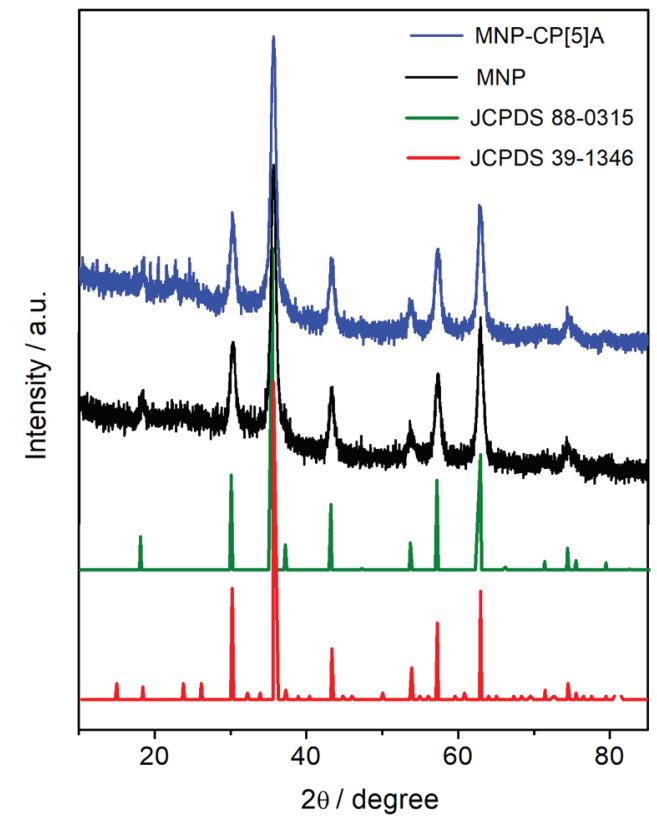

Figure 2. PXRD of MNP-CP[5]A and MNP.

TEM images (Figures 3 and S5, SI section) show a spherical shape and uniform size distribution of MNP and MNP-CP[5]A. The particle size distribution (PSD) is centered at 12 and $13 \mathrm{~nm}$ for MNP and MNP-CP[5]A, respectively, therefore, no significant size distribution changes were detected after coating MNP with CP[5]A molecules.

Figure 4 shows the magnetic characterization for MNP and MNP-CP[5]A performed at RT. The inset in Figure 4 shows the magnetization at zero magnetic field is lower than the instrument accuracy at zero magnetic field accuracy. Therefore, the absence of hysteresis, coercivity and remnant magnetization indicate the superparamagnetic nature of the materials at $\mathrm{T}=300 \mathrm{~K}$. The saturation value of the magnetization at this temperature corresponds to approximately 42.4 and $25.8 \mathrm{emu} \mathrm{g}^{-1}$ for MNP and MNP-CP[5]A, respectively, confirming both materials are mostly composed by maghemite. ${ }^{57}$ The lower saturation value of the magnetization for MNP-CP[5]A compared to MNP is due to the presence of $\mathrm{CP}[5] \mathrm{A}$ as an organic diamagnetic matter.

$\zeta$-Potential of MNP-CP[5]A and MNP was measured to evaluate the surface modification of the magnetic nanoparticles after coating with $\mathrm{CP}[5] \mathrm{A}$ as well the colloidal stability of the materials as function of $\mathrm{pH}(2-10)$. The experiments were carried out using the same concentration of both materials $\left(0.075 \mathrm{mg} \mathrm{mL}^{-1}\right)$. From Figure 5, the values of $\zeta$-potentials for both materials decrease
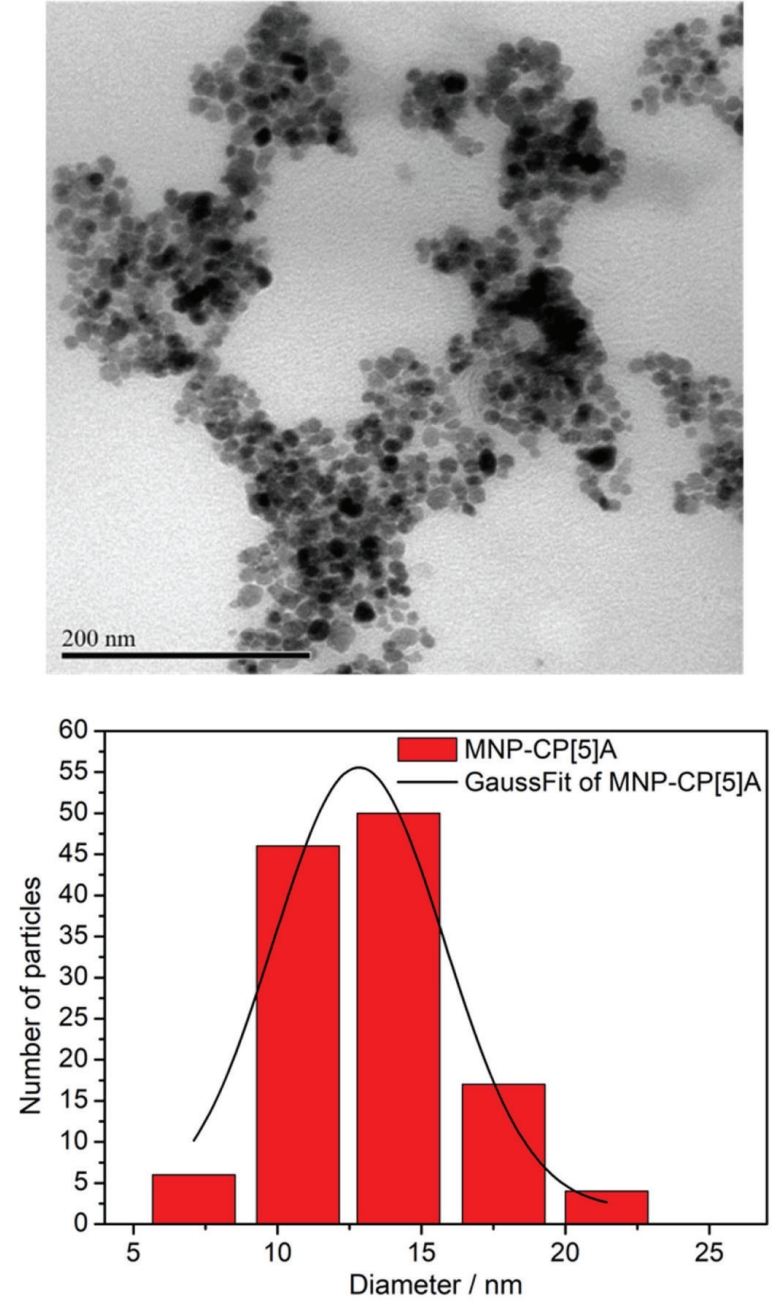

Figure 3. TEM image and particle size distribution of MNP-CP[5]A.

with increasing $\mathrm{pH}(>8)$ due to the deprotonation of hydroxyl and carboxyl groups of MNP and MNP-CP[5]A, respectively. In contrast, upon acidification of MNP dispersion (black curve) $(\mathrm{pH}<7), \zeta$-potential increased and reached positive values $(+30 \mathrm{mV}$ at $\mathrm{pH}=2)$, most likely because of protonation of the hydroxyl groups present on MNP surface. The same tendency is observed for MNP-CP[5]A (blue curve) at $\mathrm{pH}<7$, in which $\zeta$-potential values increased with decreasing $\mathrm{pH}$ values due to protonation of the carboxyl groups of CP[5]A. However, for MNP-CP[5]A, $\zeta$-potential is negative in all acid $\mathrm{pH}$ range measured $(-15 \mathrm{mV}$ at $\mathrm{pH}=2.4)$. The negative nature of MNP-CP[5]A in acid medium can be attributed to the high amount of carboxylate groups of $\mathrm{CP}$ [5]A grafted on MNP surface, decreasing the $\mathrm{pH}$ of the isoelectric point of MNPs. ${ }^{56,58,59} \zeta$-potential values at $\mathrm{pH}=7.4$ for MNP and MNP-CP[5]A are +0.46 , and $-44.48 \mathrm{mV}$, respectively. The isoelectric point (IEP) for the bare MNP is 7.5, therefore, very close to 7.4, which means this material is an unstable colloid at 


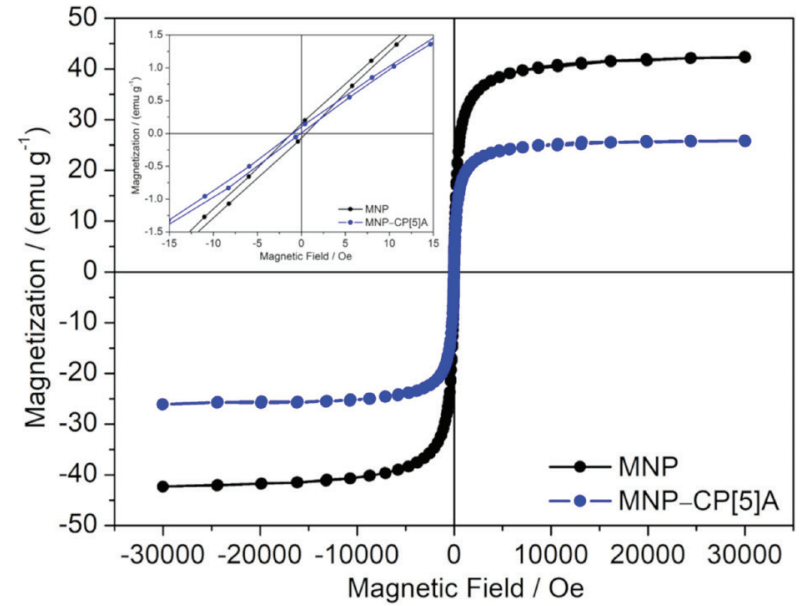

Figure 4. Field dependence of the magnetization at $300 \mathrm{~K}$ for MNP and MNP-CP[5]A. The inset figure shows a magnification around zero field at the same temperature.

physiological conditions. MNP-CP[5]A, however, shows highly negative value of $\zeta$-potential at $\mathrm{pH}=7.4$, which is desirable for biomedical applications because there is no nanoparticle aggregation at physiological conditions. The average hydrodynamic diameter obtained from dynamic light scattering (DLS) measurements at $\mathrm{pH}=7.4$ decreases from $898 \mathrm{~nm}$ for the bare MNP to $248 \mathrm{~nm}$ for MNP-CP[5]A (Figure S6, SI section) confirming, therefore, coating the SPIONs with CP[5]A decreases particle aggregation, corroborating the results obtained by $\zeta$-potential measurements.

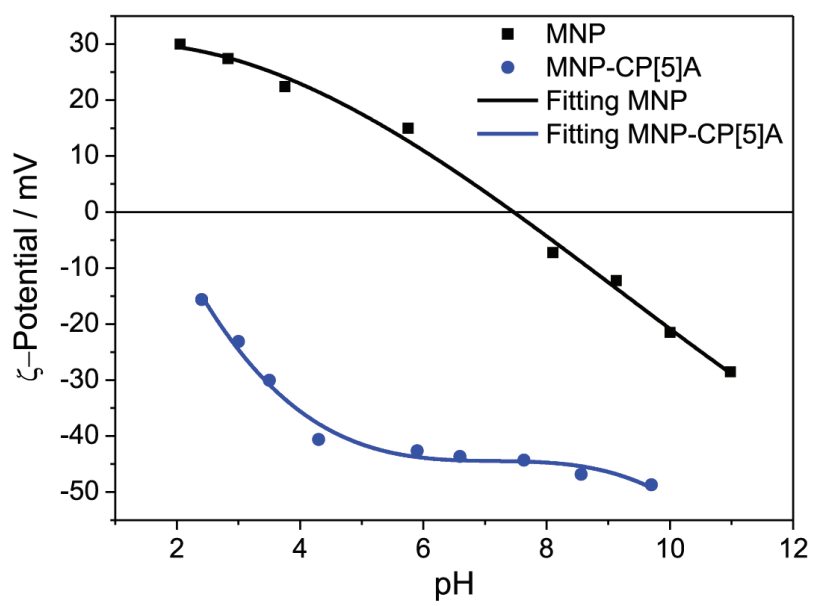

Figure 5. $\zeta$-Potential of the nanocarrier MNP-CP[5]A and MNP.

\section{Concentration-dependent heating of MNP-CP[5]A in an AMF}

To verify the potential use of MNP-CP[5]A as a magnetic hyperthermia induced agent, we investigated the magnetic heating capacity as function of the MNP-CP[5]A concentration in PBS buffer. Figure 6 shows the results of heating capacity for several concentrations under the same conditions of magnetic field, i.e., 200 Oe of amplitude and with a frequency of $307 \mathrm{kHz}$. It is worth to note that field strength and frequency product was $4.9 \times 10^{9} \mathrm{~A} \mathrm{~m}^{-1} \mathrm{~s}^{-1}$, which is considered safe to be used in physiological applications. ${ }^{60}$ For concentrations of 10,15 , and $20 \mathrm{mg} \mathrm{mL}^{-1}$ of MNP-CP[5]A, it takes 25,12 , and 8 min to reach the hyperthermia temperature of $45{ }^{\circ} \mathrm{C}$, respectively (Figure 6). For the concentrations of 1 and $5 \mathrm{mg} \mathrm{mL}^{-1}$ of MNP-CP[5]A, the dispersions did not reach the temperature of $45^{\circ} \mathrm{C}$, even for the longest acquisition time (50 $\mathrm{min})$.

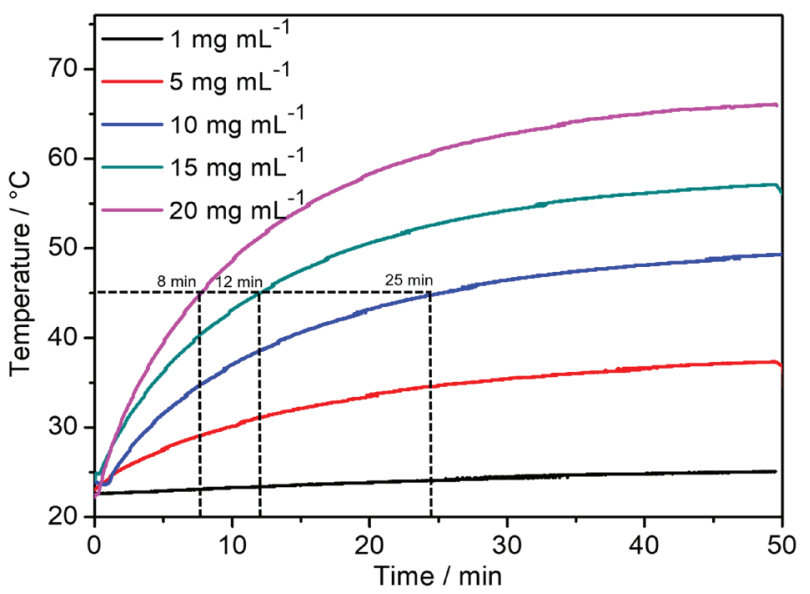

Figure 6. Magnetic heating efficiency study of the nanocarrier MNP-CP[5]A (PBS buffer, $\mathrm{pH}=7.4$ ) in different concentrations.

From the magnetic heating efficiency results shown in Figure 6 it is possible to calculate the specific absorption rate (SAR) of the MNP-CP[5]A agent. The SAR is the magnetic energy converted into heat, normalized by both, the time and the mass of the magnetic nanoparticles, during the hyperthermia essays. ${ }^{61}$ The SAR depends on the size, shape, saturation of magnetization, concentration, and interparticle magnetic interaction in the dispersion. ${ }^{62}$ To calculate the SAR of the samples it was considered the initial slope method:

$\mathrm{SAR}=\left(\mathrm{m}_{\mathrm{MNP}} \mathrm{C}_{\mathrm{MNP}}+\mathrm{m}_{\mathrm{L}} \mathrm{C}_{\mathrm{L}} / \mathrm{m}_{\mathrm{MNP}}\right) \times(\mathrm{dT} / \mathrm{dt})$

where $\mathrm{m}_{\mathrm{MNP}}$ and $\mathrm{m}_{\mathrm{L}}$ are the mass $(\mathrm{kg})$ of the nanoparticles and of the liquid, respectively; $\mathrm{C}_{\mathrm{MNP}}$ and $\mathrm{C}_{\mathrm{L}}$ are the specific heat $\left(\mathrm{J} \mathrm{kg}^{-1} \mathrm{~K}^{-1}\right)$ of the nanoparticles and the liquid; and $\mathrm{dT} / \mathrm{dt}$ is the initial slope of the temperature versus time curve (Figure 6), which is the temperature increase per time $\left(\mathrm{K} \mathrm{s}^{-1}\right){ }^{63}$ The $\mathrm{dT} / \mathrm{dt}$ values (Figure 6) used for SAR calculation were: $0.020 \mathrm{~K} \mathrm{~s}^{-1}\left(5 \mathrm{mg} \mathrm{mL}^{-1}\right), 0.043 \mathrm{~K} \mathrm{~s}^{-1}$ $\left(10 \mathrm{mg} \mathrm{mL}^{-1}\right), 0.048 \mathrm{~K} \mathrm{~s}^{-1}\left(15 \mathrm{mg} \mathrm{mL}^{-1}\right)$, and $0.075 \mathrm{~K} \mathrm{~s}^{-1}$ (20 $\left.\mathrm{mg} \mathrm{mL}^{-1}\right)$. 
The SAR is linearly dependent on the frequency (f) and quadratically dependent on the field amplitude $(\mathrm{H})$ of the AMF applied. To compare heating efficiency at different experimental conditions of amplitude and frequency of the magnetic field, intrinsic loss power (ILP) quantities were also calculated. ILP parameter allows a more suitable comparison than SAR of the results obtained in this work to the ones reported in the literature, ${ }^{64}$ because ILP is an intrinsic quantity. ILP (in $\mathrm{nH} \mathrm{m} \mathrm{kg}^{-1}$ ) values were calculated using equation $4:^{10}$

$\mathrm{ILP}=\mathrm{SAR} / \mathrm{fH}^{2}$

The calculated SAR and ILP values are displayed in Figure 7. SAR values decrease with increasing concentration of MNP-CP[5]A. According to Deatsch and Evans, ${ }^{63}$ the concentrations of MNP in the dispersions can drastically affect the two main microscopy heating process, namely Brown and Néel relaxations times. The authors argue that in high concentration range of MNP, due to the decrease in the mean interparticle distances, some collective effects take place. One of them is the increase of dipolar interparticle interaction, as the interparticles mean distance decreases, which affects the magnetic anisotropy of the system, therefore, changing the Néel relaxation time. ${ }^{65,66}$ In addition, as the nanoparticles get closer to each other agglomeration can occur, increasing Brown relaxation process substantially. Therefore, because SAR decreases with increasing concentration of MNP-CP[5]A, we suggest that most likely the total relaxation time is increasing. ${ }^{65,66}$

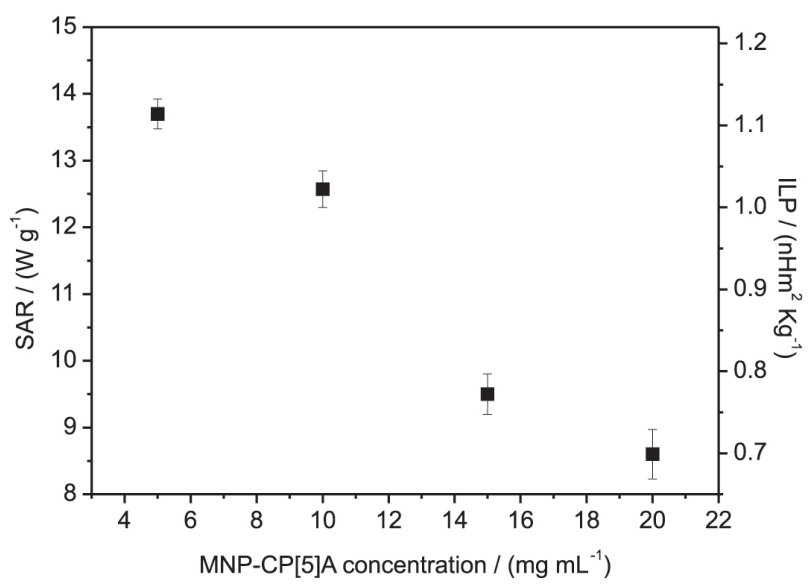

Figure 7. Specific absorption rate (SAR) and intrinsic loss power (ILP) values for MNP-CP[5]A dispersed in PBS buffer in different concentrations $\left(5,10,15,20 \mathrm{mg} \mathrm{mL}^{-1}\right)$.

The calculated ILP values for MNP-CP[5]A ranged from 0.8 to $1.2 \mathrm{nH} \mathrm{m}^{2} \mathrm{~kg}^{-1}$ depending on the concentration of the nanoparticles (Figure 7). The ILP values reported in the literature ${ }^{67}$ for commercial colloids of iron nanoparticles (ferrofluid) are in the range of 0.2 to $3.1 \mathrm{nH} \mathrm{m}^{2} \mathrm{~kg}^{-1}$. Therefore, the obtained values for MNP-CP[5]A synthesized in this work are very suitable for a possible application of this nanoplatform as a hyperthermia agent.

Investigation of $\mathrm{DOX} \subset \mathrm{CP}[5] \mathrm{A}$ interaction

${ }^{1} \mathrm{H}$ NMR spectroscopy experiments were carried out to investigate the interaction between CP[5]A and DOX (DOX $\subset \mathrm{CP}[5] \mathrm{A}$ ), Figure 8 . The spectra of pure DOX ${ }^{68,69}$ and $\mathrm{CP}[5] \mathrm{A}$ were also included in Figure 8. On addition of equimolar amount of DOX $(2.45 \mu \mathrm{mol})$ to a solution of $\mathrm{CP}[5] \mathrm{A}(2.45 \mu \mathrm{mol})$ in $\mathrm{D}_{2} \mathrm{O}$, broadening of the signals occurred indicating the presence of more than one species undergoing slow exchange on the ${ }^{1} \mathrm{H}$ NMR time scale (Figure 8b). The resonances for the hydrogens $\mathrm{H}_{c}, \mathrm{H}_{\mathrm{b}}, \mathrm{H}_{\mathrm{d}}$, and $\mathrm{H}_{\mathrm{j}}$ in DOX were shifted downfield from 7.71, 7.52, 7.44, and $5.50 \mathrm{ppm}$ to $7.95,7.66$, and $5.73 \mathrm{ppm}$, respectively, indicating interaction with $\mathrm{CP}[5] \mathrm{A}$. The chemical shifts of all the other hydrogen atoms in both the DOX and CP[5]A in the DOX $\subset \mathrm{CP}[5] \mathrm{A}$ changed dramatically as well.

To investigate the stoichiometry of this interaction, a Job plot, a method of continuous variation, was employed using UV-Vis spectroscopy (Figure 9) by monitoring the intensity of the electronic absorption band of DOX at $\lambda=483 \mathrm{~nm}$ at different molar fractions of the components (Figure 9b). Figure 9 shows two isosbestic points, in which the absorption intensity at 228 and $277 \mathrm{~nm}$ is constant throughout the experiment. The presence of isosbestic points is good evidence for the conversion of free components (DOX and CP[5]A) into complex DOX $\subset \mathrm{CP}[5]$ A. The maximum point in Job plot curve at 0.5 indicates a 1:1 binding stoichiometry between CP[5]A and DOX. Furthermore, the parabolic shape of the plot indicates an evenly distributed equilibrium..$^{70}$

\section{DOX release from MNP-CP[5]A}

DOX loading efficiency in the nanocarrier MNP-CP[5]A-DOX was $68 \%$ with a loading capacity of $9.5 \mathrm{mg} \mathrm{g}^{-1}$ of MNP-CP[5]A nanoparticles, which is ten times higher than the one obtained by our group in a previous work ${ }^{24}$ using magnetic nanoparticles functionalized with $\beta$-cyclodextrin (MNP- $\beta C D$ ) loaded with DOX, e.g. $0.81 \mathrm{mg} \mathrm{g}^{-1}$ of MNP- $\beta C D$ nanoparticles. DOX release studies in PBS buffer $(\mathrm{pH}=7.4)$ were conducted in different temperatures to evaluate the efficiency of AMF stimulus (Figure 10). The experiments were carried out at $37^{\circ} \mathrm{C}$ (body temperature) and $45^{\circ} \mathrm{C}$ (hyperthermia temperature) without AMF application using a thermostatic cuvette to control the temperature of the dispersions. Also, DOX 


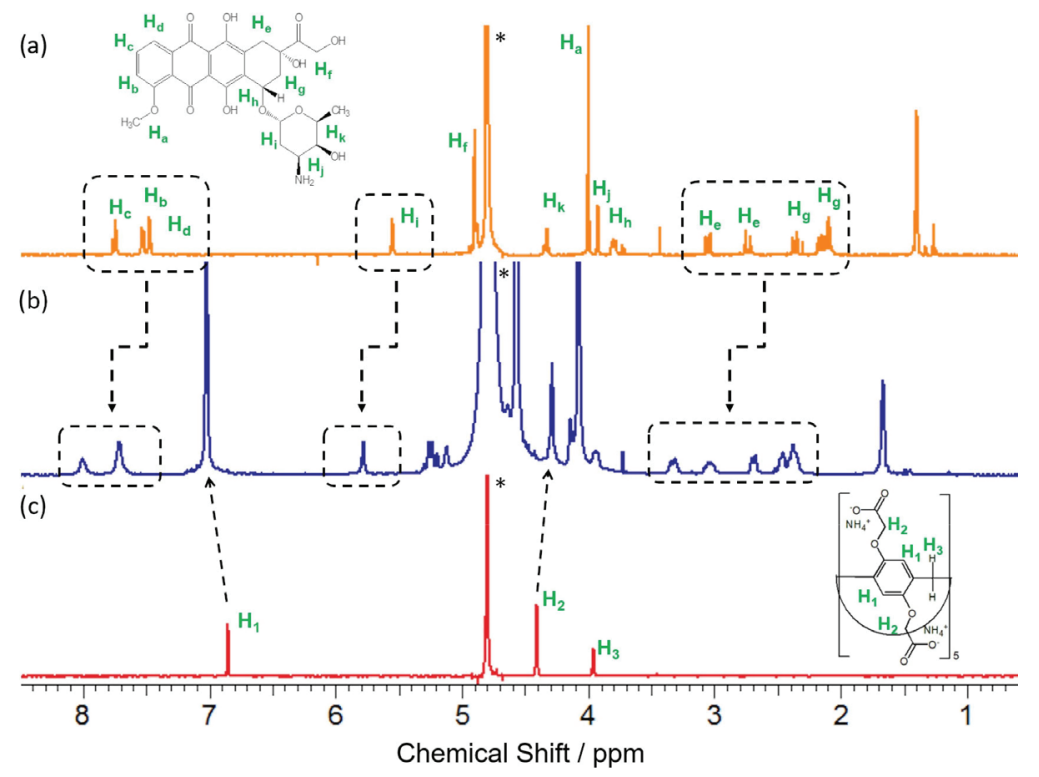

Figure 8. ${ }^{1} \mathrm{H}$ NMR spectra $\left(25^{\circ} \mathrm{C}, 500 \mathrm{MHz}, \mathrm{D}_{2} \mathrm{O}\right)$ of (a) pure DOX $\left(3.5 \mathrm{mmol} \mathrm{L}^{-1}\right)$; (b) DOX CCP 5$] \mathrm{A}(1: 1)\left(3.5 \mathrm{mmol} \mathrm{L}^{-1}\right)$; and (c) pure CP[5]A (3.5 mmol L-1).
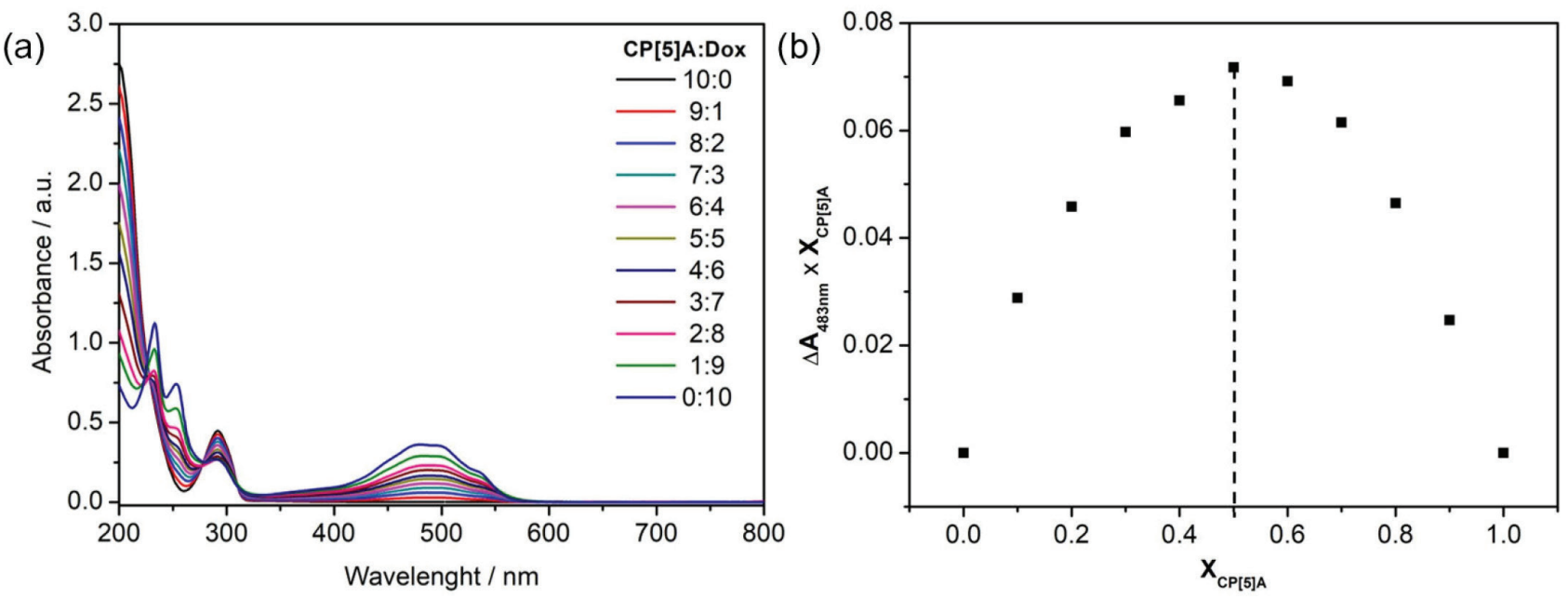

Figure 9. (a) UV-Vis spectra of mixtures of two different volumes of CP[5]A and DOX water solutions ([CP[5]A]=[DOX] $\left.=3 \times 10^{-5} \mathrm{~mol} \mathrm{~L}^{-1}\right)$ at RT; (b) Job plot of DOX $\subset \mathrm{CP}[5]$ A complex obtained from the UV-Vis data of Figure 9a.

release studies were carried out in an $\mathrm{AMF}$ at $45^{\circ} \mathrm{C}$ in PBS buffer $(\mathrm{pH}=7.4)$.

In the absence of AMF, DOX release is low (Figure 10), reaching an amount of $1.8 \mu \mathrm{g} \mathrm{mL}^{-1}(1.9 \%)$ and $3.3 \mu \mathrm{g} \mathrm{mL} \mathrm{g}^{-1}$ $(2.3 \%)$ at 37 and $45{ }^{\circ} \mathrm{C}$ within $50 \mathrm{~min}$, respectively. However, DOX release increased to $8.2 \mu \mathrm{g} \mathrm{mL}^{-1}(5.7 \%)$ within 50 min in an AMF.

In an AMF the temperature increase of MNP-CP[5]A-DOX dispersion is due to Néel and Brown relaxation processes, in which the interaction of the magnetic moments of the nanoparticles with the alternating magnetic field generates thermal energy. ${ }^{24,63}$ Because DOX is interacting through supramolecular interactions with CP[5]A, DOX release may be related to Brown relaxation process ${ }^{24}$ in which the heating is generated by the friction

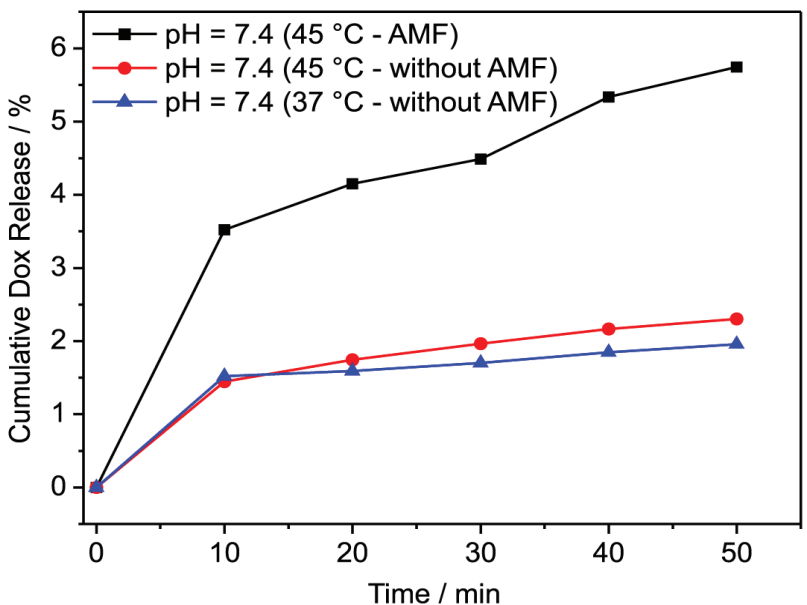

Figure 10. DOX release profile for MNP-CP[5]A-DOX in PBS buffer $(\mathrm{pH}=7.4)$ in the presence and absence of an AMF as a function of time. 
between the MNP surface and the medium. This ultimately will decrease DOX interaction with CP[5]A and DOX is released.

Although the percentage of DOX released in the AMF is low $(5.7 \%)$ relative to the total percentage of DOX loaded in MNP-CP[5]A-DOX, in terms of concentration, however, it corresponds to $0.0141 \mathrm{mmol} \mathrm{L}^{-1}$. This concentration is compatible to the $\mathrm{IC}_{50}$ (drug concentration required to inhibit cell growth by 50\%) of various types of cancer cell lines in which DOX is used (Table 1). Therefore, the result of DOX release in an AMF from the nanocarrier MNP-CP[5]A-DOX indicates this material can be applied as a potential candidate for chemo-hyperthermia therapy.

Table 1. $\mathrm{IC}_{50}$ for different doxorubicin responsive cell lines

\begin{tabular}{lcc}
\hline Cell line & Tissue sub-type & $\mathrm{IC}_{50}{ }^{a} /\left(\mathrm{mmol} \mathrm{L}^{-1}\right)$ \\
\hline KGN & ovary & 0.00616 \\
SUP-B15 & lymphoblastic, leukemia & 0.00745 \\
MCF7 & breast & 0.00984 \\
DU-4475 & breast & 0.00966 \\
ESS-1 & endometrium & 0.011 \\
$786-0$ & kidney & 0.0112 \\
PA-1 & ovary & 0.0117 \\
MV-4-11 & leukemia & 0.0117 \\
\hline
\end{tabular}

The conditions employed to determine $\mathrm{IC}_{50}$ (drug concentration required to inhibit cell growth by $50 \%$ ) values were obtained from reference 71 .

\section{Conclusions}

In summary, the design, synthesis, characterization, and operation of a nanodevice based on magnetic nanoparticles coated with carboxylate-substituted pillar[5] arene (CP[5]A) aiming target chemo-hyperthermia therapy were investigated. Superparamagnetic nanoparticles of $12 \mathrm{~nm}$ (TEM) were successfully obtained by the coprecipitation method. The surface modification of MNPs with CP[5]A improved the colloidal stability of the MNPs. Moreover, from Job plot, $\mathrm{CP}[5] \mathrm{A}$ can interact with DOX in water forming a complex $\mathrm{DOX} \subset \mathrm{CP}[5] \mathrm{A}$ in 1:1 binding stoichiometry. MNP-CP[5]A showed high DOX loading and magnetic heating capacities.

The temperature increase by using different heating sources, e.g. thermoelectric or alternating magnetic field stimuli, can trigger DOX release from the nanocarrier. However, the amount of DOX release at $45^{\circ} \mathrm{C}$ using AMF stimulus is two and a half times higher than in the absence of AMF in the same temperature. Improvement of DOX release in AMF occurs mainly due to the friction between the surface of the loaded nanocarrier and the solution (Brown relaxation process), which will increase the temperature of the solution (magnetic hyperthermia process) weakening the binding between the pillar[5]arene and the drug. In addition, MNP-CP[5]A-DOX displayed an amount of DOX release compatible with $\mathrm{IC}_{50}$ of many kinds of cancer cells. Therefore, MNP-CP[5]A-DOX can be considered a potential drug delivery system.

\section{Supplementary Information}

Supplementary information (CP[5]A synthesis scheme, ${ }^{1} \mathrm{H}$ and ${ }^{13} \mathrm{C}$ NMR CP[5]A data, ATR-FTIR spectra of $\mathrm{P}$ [5]A and MNP-CP[5]A, thermogravimetric analysis MNP-CP[5]A, TEM and PSD of MNP, DLS measurements of MNP and MNP-CP[5]A, and calibration curves of DOX in water and PBS buffer) is available free of charge at http://jbcs.sbq.org.br as PDF file.

\section{Acknowledgments}

This work was financially supported by the Brazilian agencies National Council for Scientific and Technological Development (CNPq grant number 434141/2018-6 and C. M. R. research fellowship grant number 313799/2017-2), Brazilian Federal Agency for Support and Evaluation of Graduate Education (CAPES-PrInt grant number $88887310269 / 2018-00$ and code 001, and T. S. F. and E. C. S. S. fellowships) and Rio de Janeiro Research Foundation (FAPERJ, grant number E11/2018-241023). We are grateful to the Material Characterization (http:// www.uff.br/lamate/), Molecular Spectroscopy (http://www. uff.br/lame/), NMR (http://www.laremn.uff.br), Electron Microscopy and X-ray Diffraction (http://www.ldrx.uff. br) Multiuser Laboratories from Universidade Federal Fluminense (UFF). The authors are also grateful to MSc Alan Moraes for assistance with the TEM images.

\section{References}

1. Beik, J.; Abed, Z.; Ghoreishi, F. S.; Hosseini-Nami, S.; Mehrzadi, S.; Shakeri-Zadeh, A.; Kamrava, S. K.; J. Controlled Release 2016, 235, 205.

2. DeNardo, G. L.; DeNardo, S. J.; Cancer Biother. Radiopharm. 2008, 23, 671 .

3. Périgo, E. A.; Hemery, G.; Sandre, O.; Ortega, D.; Garaio, E.; Plazaola, F.; Teran, F. J.; Appl. Phys. Rev. 2015, 2, 41302.

4. Behrouzkia, Z.; Joveini, Z.; Keshavarzi, B.; Eyvazzadeh, N.; Aghdam, R. Z.; Oman Med. J. 2016, 31, 89.

5. van der Zee, J.; Ann. Onc. 2002, 13, 1173.

6. Silva, J. S. F.; Silva, J. Y. R.; De Sá, G. F.; Araújo, S. S.; Filho, M. A. G.; Ronconi, C. M.; Santos, T. C.; Júnior, S. A.; ACS Omega 2018, 3, 12147. 
7. Kumar, C. S. S. R.; Mohammad, F.; Adv. Drug Delivery Rev. 2011, 63, 789.

8. Das, P.; Colombo, M.; Prosperi, D.; Colloids Surf., B 2019, 174, 42.

9. Moros, M.; Idiago-López, J.; Asín, L.; Moreno-Antolín, E.; Beola, L.; Grazú, V.; Fratila, R. M.; Gutiérrez, L.; de la Fuente, J. M.; Adv. Drug Delivery Rev. 2019, 138, 326.

10. Wildeboer, R. R.; Southern, P.; Pankhurst, Q. A.; J. Phys. D: Appl. Phys. 2014, 47, 495003.

11. Hauser, A. K.; Wydra, R. J.; Stocke, N. A.; Anderson, K. W.; Hilt, J. Z.; J. Controlled Release 2015, 219, 76.

12. Kuo, C.; Liu, T.; Chan, T.; Tsai, S.; Hardiansyah, A.; Huang, L.; Yang, M.; Lu, R.; Jiang, J.; Yang, C.; Lin, C.-H.; Chiu, W.-Y.; Colloids Surf., B 2016, 140, 567.

13. Santos, E. C. S.; dos Santos, T. C.; Guimarães, R. B.; Ishida, L.; Freitas, R. S.; Ronconi, C. M.; RSC Adv. 2015, 5, 48031.

14. da Silva, G. B.; Marciello, M.; Morales, M. D. P.; Serna, C. J.; Vargas, M. D.; Ronconi, C. M.; Costo, R.; J. Braz. Chem. Soc. 2017, 28, 731 .

15. Mohammed, L.; Gomaa, H. G.; Ragab, D.; Zhu, J.; Particuology 2017, 30, 1 .

16. Ventola, C. L.; $P \& T^{\circledast} \mathbf{2 0 1 7}, 42,742$.

17. Caster, J. M.; Patel, A. N.; Zhang, T.; Wang, A.; WIREs Nanomed. Nanobiotechnol. 2017, 9, 1.

18. Laurent, S.; Forge, D.; Port, M.; Roch, A.; Robic, C.; Vander Elst, L.; Muller, R. N.; Chem. Rev. 2008, 108, 2064.

19. Fan, H.; Li, B.; Shi, Z.; Zhao, L.; Wang, K.; Qiu, D.; Ceram. Int. 2018, 44, 2345.

20. Kostiv, U.; Patsula, V.; Šlouf, M.; Pongra, I. M.; Škokić, S.; Radmilović, M. D.; Pavičić, I.; Vrček, I. V.; And, S. G.; Horák, D.; RSC Adv. 2017, 7, 8786.

21. Silveira, G. Q.; Ronconi, C. M.; Vargas, M. D.; San Gil, R. A. S.; Magalhães, A.; J. Braz. Chem. Soc. 2011, 22, 961.

22. Gutiérrez, L.; Romero, S.; da Silva, G. B.; Costo, R.; Vargas, M. D.; Ronconi, C. M.; Serna, C. J.; Veintemillas-Verdaguer, S.; Del Puerto Morales, M.; Biomed. Tech. 2015, 60, 417.

23. Rojas, J. M.; Gavilán, H.; del Dedo, V.; Lorente-Sorolla, E.; Sanz-Ortega, L.; da Silva, G. B.; Costo, R.; Perez-Yagüe, S.; Talelli, M.; Marciello, M.; Morales, M. P.; Barber, D. F.; Gutiérrez, L.; Acta Biomater. 2017, 58, 181.

24. Santos, E. C. S.; Watanabe, A.; Vargas, M. D.; Tanaka, M. N.; Garcia, F.; Ronconi, C. M.; New J. Chem. 2018, 42, 671.

25. Silveira, G. Q.; Vargas, M. D.; Ronconi, C. M.; J. Mater. Chem. 2011, 21, 6034.

26. Silveira, G. Q.; da Silva, R. S.; Franco, L. P.; Vargas, M. D.; Ronconi, C. M.; Microporous Mesoporous Mater. 2015, 206, 226.

27. Benyettou, F.; Fahs, H.; Elkharrag, R.; Bilbeisi, R. A.; Asma, B.; Rezgui, R.; Motte, L.; Magzoub, M.; Brandel, J.; Olsen, J.; Piano, F.; Gunsalus, K. C.; Platas-Iglesias, C.; Trabolsi, A.; RSC Adv. 2017, 7, 23827.
28. Benyettou, F.; Alhashimi, M.; Connor, M. O.; Pasricha, R.; Brandel, J.; Traboulsi, H.; Mazher, J.; Olsen, J.; Trabolsi, A.; ACS Appl. Mater. Interfaces 2017, 9, 40006.

29. Chin, S. F.; Makha, M.; Raston, L.; Saunders, M.; Chem. Commun. 2007, 1948.

30. Sathiyajith, C. W.; Shaikh, R. R.; Han, Q.; Zhang, Y.; Meguellati, K.; Yang, Y. W.; Chem. Commun. 2017, 53, 677.

31. Cragg, P. J.; Isr. J. Chem. 2018, 58, 1194.

32. Song, N.; Kakuta, T.; Yamagishi, T.; Yang, Y.; Ogoshi, T.; Chem 2018, 4, 2029.

33. Li, Q. L.; Sun, Y.; Ren, L.; Wang, X.; Wang, C.; Li, L.; Yang, Y. W.; Yu, X.; Yu, J.; ACS Appl. Mater. Interfaces 2018, 10, 29314.

34. Li, H.; Wei, R.; Yan, G. H.; Sun, J.; Li, C.; Wang, H.; Shi, L.; Capobianco, J. A.; Sun, L.; ACS Appl. Mater. Interfaces 2018, 10,4910 .

35. Yu, G.; Zhou, J.; Shen, J.; Tang, G.; Huang, F.; Chem. Sci. 2016, $7,4073$.

36. Hu, X.; Liu, X.; Zhang, W.; Qin, S.; Yao, C.; Li, Y.; Cao, D.; Peng, L.; Wang, L.; Chem. Mater. 2016, 28, 3778.

37. Chang, Y.; Yang, K.; Wei, P.; Huang, S.; Pei, Y.; Zhao, W.; Pei, Z.; Angew. Chem., Int. Ed. 2014, 53, 13126.

38. Jiang, L.; Huang, X.; Chen, D.; Yan, H.; Li, X.; Du, X.; Angew. Chem., Int. Ed. 2017, 56, 2655.

39. Xiao, T.; Zhong, W.; Xu, L.; Sun, X.; Hu, X.; Wang, L.; Org. Biomol. Chem. 2019, 17, 1336.

40. Yao, Y.; Xue, M.; Chen, J.; Zhang, M.; Huang, F.; J. Am. Chem. Soc. 2012, 134, 15712.

41. Zhou, J.; Chen, M.; Diao, G.; ACS Appl. Mater. Interfaces 2014 , $6,18538$.

42. Tan, L.; Li, H.; Zhou, Y.; Zhang, Y.; Feng, X.; Wang, B.; Yang, Y.-W.; Small 2015, 11, 3807.

43. Huang, X.; Du, X.; ACS Appl. Mater. Interfaces 2014, 6, 20430.

44. Tan, L.-L.; Li, H.; Qiu, Y.-C.; Chen, D.-X.; Wang, X.; Pan, R.-Y.; Wang, Y.; Zhang, S. X.-A.; Wang, B.; Yang, Y.-W.; Chem. Sci. 2015, 6, 1640.

45. Sun, Y. L.; Yang, Y. W.; Chen, D. X.; Wang, G.; Zhou, Y.; Wang, C. Y.; Stoddart, J. F.; Small 2013, 9, 3224.

46. Wu, M.; Yan, H.; Gao, J.; Cheng, Y.; Yang, J.; Wu, J.; Gong, B.; Zhang, H.; Yang, Y.; ACS Appl. Mater. Interfaces 2018, 10, 34655 .

47. Li, X.; Han, J.; Wang, X.; Zhang, Y.; Jia, C.; Qin, J.; Wang, C.; Wu, J.-R.; Fang, W.; Yang, Y.-W.; Mater. Chem. Front. 2019, 3,103 .

48. Zhang, H.; Wu, J. R.; Wang, X.; Li, X.-S.; Wu, M.-X.; Liang, F.; Yang, Y.-W.; Dyes Pigm. 2019, 162, 512.

49. Tian, M. M.; Chen, D. X.; Sun, Y. L.; Yang, Y. W.; Jia, Q.; RSC Adv. 2013, 3, 22111.

50. Wu, M.-X.; Gao, J.; Wang, F.; Yang, J.; Song, N.; Jin, X.; Mi, P.; Tian, J.; Luo, J.; Liang, F.; Yang, Y.-W.; Small 2018, 14, 1704440 . 
51. Ogoshi, T.; Aoki, T.; Kitajima, K.; Fujinami, S.; Yamagishi, T.; Nakamoto, Y.; J. Org. Chem. 2011, 76, 328.

52. Li, H.; Chen, D.-X.; Sun, Y.-L.; Zheng, Y. B.; Tan, L.-L.; Weiss, P. S.; Yang, Y.-W.; J. Am. Chem. Soc. 2013, 135, 1570.

53. Li, C.; Shu, X.; Li, J.; Chen, S.; Han, K.; Xu, M.; Hu, B.; Yu, Y.; Jia, X.; J. Org. Chem. 2011, 76, 8458.

54. Massart, R.; IEEE Trans. Magn. 1981, 17, 1247.

55. Costo, R.; Bello, V.; Robic, C.; Port, M.; Marco, J. F.; Puerto Morales, M.; Veintemillas-Verdaguer, S.; Langmuir 2012, 28, 178.

56. Tombácz, E.; Szekeres, M.; Hajdú, A.; Tóth, I. Y.; Bauer, R. A.; Nesztor, D.; Illés, E.; Zupkó, I.; Vékás, L.; Period. Polytech., Chem. Eng. 2014, 58, 3.

57. Rahman, M.; Usman, M.; Ullah, A.; Zulfiqar, S.; J. Korean Phys. Soc. 2014, 65, 1925.

58. Szekeres, M.; Tóth, I. Y.; Illés, E.; Hajdú, A.; Zupkó, I.; Farkas, K.; Oszlánczi, G.; Tiszlavicz, L.; Tombácz, E.; Int. J. Mol. Sci. 2013, 14, 14550.

59. Atacan, K.; Kursunlu, A. N.; Ozmen, M.; Mater. Sci. Eng., C 2019, 94, 886.

60. Hergt, R.; Dutz, S.; J. Magn. Magn. Mater. 2007, 311, 187.

61. Nemati, Z.; Alonso, J.; Khurshid, H.; Phan, M. H.; Srikanth, H.; RSC Adv. 2016, 6, 38697.

62. Shubitidze, F.; Kekalo, K.; Stigliano, R.; Baker, I.; J. Appl. Phys. 2015, 117, 094302.
63. Deatsch, A. E.; Evans, B. A.; J. Magn. Magn. Mater. 2014, 354, 163.

64. de Mello, L. B.; Varanda, L. C.; Sigoli, F. A.; Mazali, I. O.; J. Alloys Compd. 2019, 779, 698.

65. Piñeiro-Redondo, Y.; Bañobre-López, M.; Pardiñas-Blanco, I.; Goya, G.; López-Quintela, M. A.; Rivas, J.; Nanoscale Res. Lett. 2011, 6, 383.

66. Linh, P. H.; Van Thach, P.; Tuan, N. A.; Thuan, N. C.; Manh, D. H.; Phuc, N. X.; Van Hong, L.; J. Phys.: Conf. Ser. 2009, 187,6 .

67. Kallumadil, M.; Tada, M.; Nakagawa, T.; Abe, M.; Southern, P.; Pankhurst, Q. A.; J. Magn. Magn. Mater. 2009, 321, 1509.

68. Wang, Y.; Wang, R.; Lu, X.; Lu, W.; Zhang, C.; Liang, W.; Pharm. Res. 2010, 27, 361.

69. Lu, J.; Zhao, W.; Huang, Y.; Liu, H.; Marquez, R.; Gibbs, R. B.; Li, J.; Venkataramanan, R.; Xu, L.; Li, S.; Li, S.; Mol. Pharm. 2014, 11, 4164.

70. Corda, E.; Hernandez, M.; Sanchez-Cortes, S.; Sevilla, P.; Colloids Surf., A 2018, 557, 66.

71. https://www.cancerrxgene.org/translation/Drug/133, accessed on February 15, 2019. 